\title{
PANCYTOPENIA- A CLINICO-HAEMATOLOGICAL STUDY
}

\author{
Jocelyn Sara Paul1, Sheeja S2, S. Sankar ${ }^{3}$
}

1 Postgraduate Student, Department of Pathology, Government Medical College, Kottayam, Kerala.

${ }^{2}$ Associate Professor (CAP), Department of Pathology, Government Medical College, Kottayam, Kerala.

3 Professor and HOD, Department of Pathology, Government Medical College, Kottayam, Kerala.

\section{BACKGROUND}

ABSTRACT

Pancytopenia is an important clinico-haematological entity encountered in our daily clinical practice. There are varying clinical patterns, treatment modalities and outcomes for pancytopenia. The severity of pancytopenia and the underlying pathology determine the management and prognosis of the patient. Hence, the evaluation of the various causes of pancytopenia could aid in planning the diagnostic and therapeutic approach in patients with pancytopenia. Megaloblastic anaemia is one of the major causes of pancytopenia in India.

The objectives are to identify the various causes of pancytopenia, to describe the clinical and haematological parameters in pancytopenia.

\section{MATERIALS AND METHODS}

A descriptive study on 80 cases was conducted to describe the various causes of pancytopenia in the peripheral blood, bone marrow aspirate and trephine biopsy samples of pancytopenia patients received in the Department of Pathology, Government Medical College, Kottayam during a period of 12 months (June 2016 - May 2017).

\section{RESULTS}

Among the 80 cases of pancytopenia studied, common causes were megaloblastic anaemia (18 cases, 23\%) and acute lymphoblastic leukaemia ( 9 cases, 11\%). Majority of the patients had a hypercellular bone marrow (70\%).

\section{CONCLUSION}

Most common cause of pancytopenia was megaloblastic anaemia followed by acute leukaemia.

\section{KEY WORDS}

Pancytopenia; Megaloblastic Anaemia; Hypercellular.

HOW TO CITE THIS ARTICLE: Paul JS, Sheeja S, Sankar S. Pancytopenia- a clinico-haematological study. J. Evolution Med. Dent. Sci. 2018;7(16):1984-1988, DOI: 10.14260/jemds/2018/446

\section{BACKGROUND}

Pancytopenia is an important clinico-haematological entity encountered in our daily clinical practice. There are varying clinical patterns, treatment modalities and outcomes for pancytopenia. ${ }^{1}$ Pancytopenia is a combination of anaemia, leukopenia and thrombocytopenia with Haemoglobin $<13.5$ $\mathrm{gm} / \mathrm{dL}$ in men and $<11.5 \mathrm{gm} / \mathrm{dL}$ in women, Total leucocyte count $<4000 /$ cumm and Platelet count $<1,50,000 / \mathrm{dL}^{2}$

Neutropenia, where absolute neutrophil count is less than $1500 /$ cumm is considered more important than leukopenia. Pancytopenia is not a disease, but a haematological manifestation of various disease processes, primarily or secondarily involving the bone marrow. ${ }^{1}$ It is a striking feature of many serious and life-threatening illnesses and may be caused by several disorders ranging from simple drug-induced bone marrow hypoplasia and megaloblastic anaemia to the fatal aplastic anaemia and leukaemias. ${ }^{3}$

'Financial or Other Competing Interest': None.

Submission 19-01-2018, Peer Review 30-03-2018,

Acceptance 04-04-2018, Published 16-04-2018.

Corresponding Author:

Dr. Sheeja $S$,

Department of Pathology,

Government Medical College,

Kottayam-686008,

Kerala.

E-mail:drsheejas@yahoo.com

DOI: $10.14260 /$ jemds $/ 2018 / 446$
Clinically pancytopenia can have varied presentations like generalised weakness, fever, weight loss, breathlessness, bleeding manifestations, pallor, jaundice, splenomegaly hepatomegaly, bone tenderness and lymphadenopathy. ${ }^{1}$ The presenting symptoms are attributed to anaemia, leukopenia or thrombocytopenia. Some cases of pancytopenia can be transient, that is it lasts only for 1 to 2 weeks. Drugs or viral infections should be considered as aetiology for transient

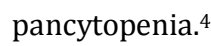

Pancytopenia is usually detected by performing a complete blood count (CBC). Peripheral smear examination reveals important information regarding pancytopenia, for e.g. macro-ovalocytes with hypersegmented neutrophils in megaloblastic anaemia, occasional blast cells in subleukaemic leukaemia, leucoerythroblastic blood picture in myelofibrosis and Pelger-Huet neutrophils in myelodysplastic syndrome. 4

Bone marrow examination gives further information regarding the aetiology, for e.g. hypoplastic/ fibrotic marrow in aplastic anaemia, marrow necrosis in myelodysplastic syndrome, acute leukaemia and hairy cell leukaemia, dry tap in myelofibrosis, granulomas in granulomatous diseases like tuberculosis and brucellosis. Additional investigations like immunophenotyping and cytogenetic analysis can be done if resources and facilities are available. ${ }^{5}$

The severity of pancytopenia and the underlying pathology determine the management and prognosis of the patient. Therefore, it is very crucial to perform complete investigations in order to determine the cause and decide the 
treatment modality. Treating the aetiology is the mainstay of management as in Vitamin B12, folic acid supplementation in megaloblastic anaemia, interferon therapy for hairy-cell leukaemia, specific chemotherapy for acute leukaemia/myelodysplastic syndrome (MDS) and antituberculous treatment (ATT) for tuberculosis. ${ }^{5}$

In India, many studies on pancytopenia have been conducted. These studies show that megaloblastic anaemia is the most common cause of pancytopenia. ${ }^{1}$ The other causes being aplastic anaemia, hypersplenism, leukaemia, MDS and infections. The available literature on review shows limited studies of pancytopenia from the state of Kerala. Hence, the present study has been undertaken in this tertiary care centre to evaluate the various clinical presentations of pancytopenia excluding transient cases and to describe the peripheral blood and bone marrow findings where available. This study will help in finding the various causes of pancytopenia in this hospital, which could aid in planning the diagnostic and therapeutic approach in patients with pancytopenia.

\section{MATERIALS AND METHODS}

A descriptive study on 80 cases was conducted to describe the various causes of pancytopenia in the peripheral blood, bone marrow aspirate and trephine biopsy samples of pancytopenia patients received in the Department of Pathology, Government Medical College, Kottayam during a period of 12 months (June 2016 - May 2017).

Inclusion Criteria- Patients with haemoglobin value less than $10 \mathrm{gm} / \mathrm{dL}$, total leucocyte count less than 4000/cumm and platelet count less than 1,00,000/cumm.

Exclusion Criteria- Patients on chemotherapy or radiotherapy, transient cases of pancytopenia (lasting less than 2 weeks) and patients who are not willing for study.

\section{Study Procedure}

Clinical data of individual patients who satisfy the criteria for pancytopenia and excluding transient cases of pancytopenia and patients on radiotherapy or chemotherapy will be collected and compiled. Complete haematological parameters including haemoglobin, WBC count, platelet count, differential count, RBC count, MCV, MCH and MCHC are obtained with the help of an automated haematological analyser. Reticulocyte count is done manually.

Peripheral smear is prepared and stained using Leishman's stain. Bone marrow aspirate smears are also stained with Leishman's stain. Special stains are done in cases of acute leukaemia, megaloblastic anaemia, myelodysplastic syndrome and other relevant cases.

Trephine biopsy specimens received in Bouin's fluid in the histopathology department is initially decalcified and then processed. Bone marrow reticulin stain is routinely done in all cases. Bone marrow iron studies are carried out in relevant cases like megaloblastic anaemia and myelodysplastic syndrome. Vit B12 levels and cytogenetics data in available cases are taken into account.

\section{Data Management and Analysis}

Ratio, proportion and frequency is used.

\section{RESULTS}

80 cases of pancytopenia were studied during the period of June 2016 to May 2017 in Department of Pathology, Kottayam Medical College. The findings after appropriate statistical analysis are given as follows.

- The commonest cause of pancytopenia was megaloblastic anaemia (23\%) followed by acute lymphoblastic leukaemia (11\%).

- The mean age of presentation was 45.6 years. Majority of patients ( 25 cases) were in the age group of 51 to 60 years.

- An overall male preponderance resulting in a Male-toFemale ratio of 1.3: 1 was seen.

- Commonest presenting complaint was generalised weakness/fatigue (72\%) followed by fever (45\%), $14 \%$ had palpitation, $12 \%$ had dyspnoea and $11 \%$ had bleeding.

- Common clinical signs were pallor (69\%) followed by splenomegaly (52\%), hepatomegaly (30\%), lymphadenopathy (21\%) and icterus $2 \%$.

- $\quad$ The haemoglobin concentration varied from 2.9 to 9.8 $\mathrm{gm} / \mathrm{dL}$ with a mean value of $7.1 \mathrm{gm} / \mathrm{dL}$ (SD- 1.86). $36 \%$ of the patients had values between 8.1 to $10.0 \mathrm{gm} / \mathrm{dL}$, $35 \%$ had values between 6.0 to $8.0 \mathrm{gm} / \mathrm{dL}$ and $29 \%$ had values less than or equal to $6.0 \mathrm{gm} / \mathrm{dL}$.

- Total leucocyte count varies from $300-3900 / \mathrm{mm} 3$ with majority of patients (39\%) in the range of 3001 $4000 / \mathrm{mm} 3$ with a mean of $2580 / \mathrm{mm} 3$ (SD- 1008.4).

- The platelet count ranges from 7000 to $90000 / \mathrm{mm} 3$ with a mean count of 53070 cells/mm3 (SD 2600.25). About $14 \%$ had severe thrombocytopenia with values less than $20000 / \mathrm{mm} 3$.

- Red cell morphology of the studied population was normocytic normochromic in 28 cases, macrocytic in 27, microcytic hypochromic in 13 and dimorphic in 12 cases.

- The majority of patients had hypercellular marrow (70\%). $15 \%$ of patients had hypocellular marrow and $8 \%$ had normocellular marrow.

- The marrow of majority of the patients showed normoblastic maturation (43\%), 35\% had megaloblastic maturation and $21 \%$ showed erythroid suppression.

\section{Photomicrographs}

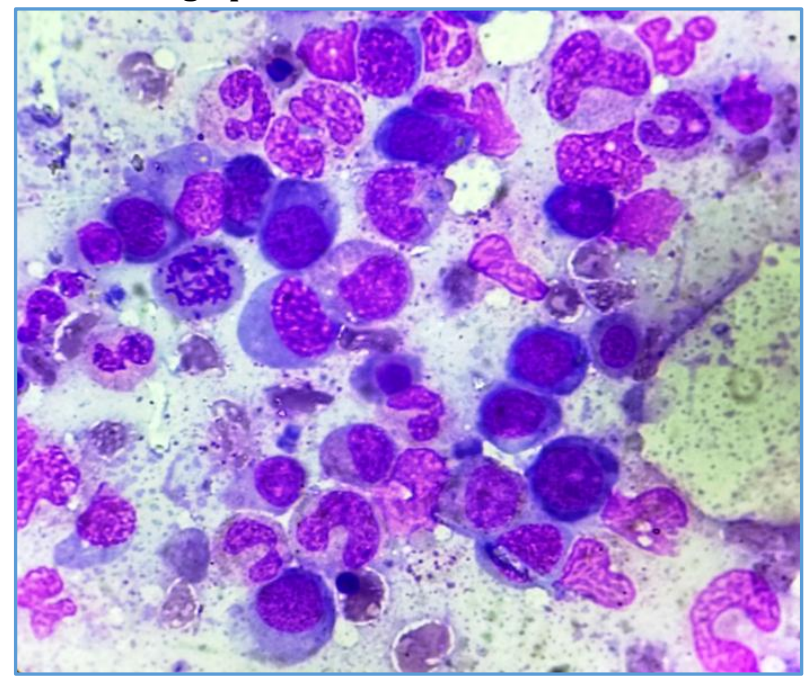

Figure 1. Megaloblastic Anaemia-Megaloblasts, Giant Stab and Metamyelocyte in BM Aspirate (100x) 


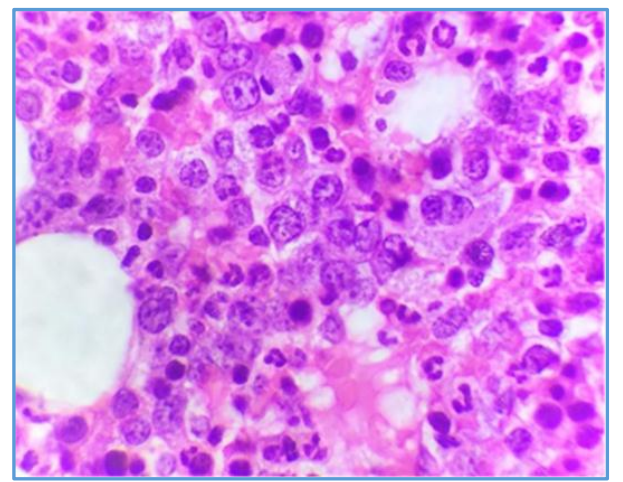

Figure 2. Megaloblastic Anaemia-BM Trephine shows Megaloblastic Maturation (100x)

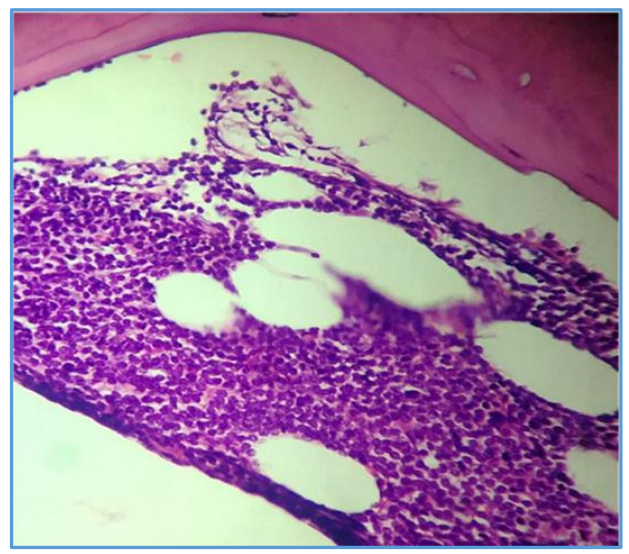

Figure 3. Acute Lymphoblastic Leukaemia- Trephine Biopsy showing Blasts (40x)

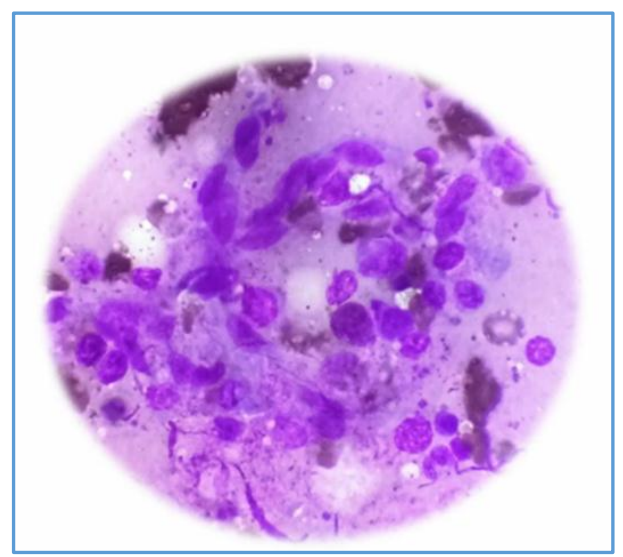

Figure 4. BM Aspirate showing Collections of Histiocytes (100X)

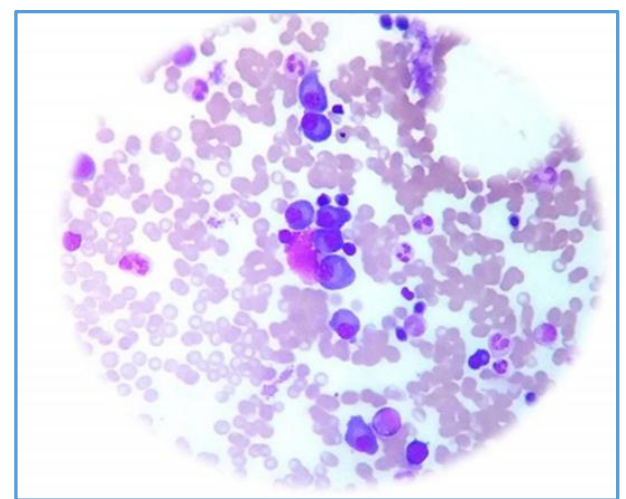

Figure 5. Plasma Cell Myeloma-BM Aspirate showing Increased Number of Plasma Cells (40x)

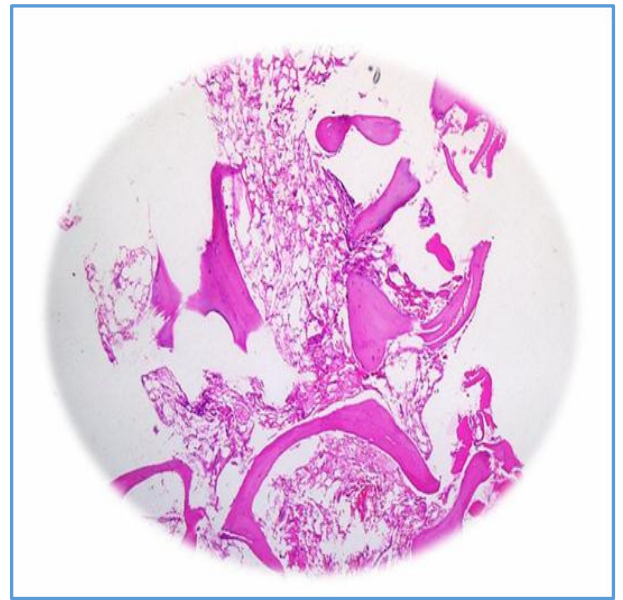

Figure 6. Aplastic Anaemia BM Biopsy (4x)

\section{DISCUSSION}

Pancytopenia is an important clinico-haematological entity, in which all three major formed elements of blood (red blood cells, white blood cells and platelets) are simultaneously decreased in number.

This study was carried out with an aim to identify the common causes of pancytopenia and describe the different types of clinical presentations in this tertiary care centre, so that it would help in the management of patients.

80 cases of pancytopenia were diagnosed during the period of study with the following aetiology.

\begin{tabular}{|c|c|c|}
\hline Diagnosis & No. of Cases & \% \\
\hline Megaloblastic anaemia & 18 & 23 \\
\hline Acute leukaemia- lymphoblastic & 9 & 11 \\
\hline Myelodysplastic syndrome & 6 & 8 \\
\hline Lymphoma & 6 & 8 \\
\hline Hypoplastic marrow & 6 & 8 \\
\hline Hypersplenism & 3 & 4 \\
\hline Acute leukaemia- myeloid & 3 & 4 \\
\hline Multiple myeloma & 3 & 4 \\
\hline Aplastic anaemia & 3 & 4 \\
\hline Plasmacytosis & 2 & 2 \\
\hline Chronic granulomatous lesion & 2 & 2 \\
\hline Myelofibrosis & 2 & 2 \\
\hline Leukaemia/Lymphoma & 1 & 1 \\
\hline Macrophage activation syndrome & 1 & 1 \\
\hline Marrow necrosis & 1 & 1 \\
\hline Paroxysmal nocturnal haemoglobinuria & 1 & 1 \\
\hline No definite opinion & 13 & 16 \\
\hline Table 1. List of Causes of Pancytopenia in the \\
\hline \multicolumn{2}{|c|}{ Present Study } & \\
\hline
\end{tabular}

The common causes of pancytopenia were Megaloblastic anaemia (23\%), Acute lymphoblastic leukaemia (11\%), Myelodysplastic syndrome (8\%), Hypoplastic marrow (8\%) and Lymphoma (8\%).

A study conducted by Jitendar Mohan Khunger et al on 200 patients showed that commonest cause of pancytopenia was megaloblastic anaemia (72\%). Other causes being aplastic anaemia (14\%), sub-leukaemic leukaemia (5\%), hypersplenism (2\%) and MDS (2\%). ${ }^{2}$

A study by Kumar et al on 166 cases of pancytopenia showed that four main causes were aplastic anaemia (49 cases), megaloblastic anaemia (37 cases), aleukaemic 
leukaemia/lymphoma (30 cases) and hypersplenism (19 cases). ${ }^{6}$

Jan et al had reported $23.9 \%$ of haematological malignancies presenting with pancytopenia in the paediatric age group, of which acute lymphoblastic leukaemia was the commonest with $11.7 \%$ of cases. ${ }^{7}$ In a study by Gupta et al in children, aplastic anaemia was the most common cause of pancytopenia (43\%) followed by acute leukaemia (25\%). ${ }^{8} \mathrm{~A}$ study conducted by Gayathri and Rao et al on 104 patients showed that the commonest cause of pancytopenia was megaloblastic anaemia (74.4\%) followed by aplastic anaemia $(18.26 \%){ }^{1}$ The high prevalence of nutritional anaemia in India is accountable for the increased frequency of megaloblastic anaemia. ${ }^{1}$

This study shows six (8\%) cases of pancytopenia due to MDS. Among these, one case was Refractory Anaemia with Excessive Blasts (RAEB) type. The incidence of MDS as reported in other similar studies varies from 0 to $18 \% .^{3}$ MDS are most common in the elderly and should be included in the differential diagnosis of elderly patients with pancytopenia. This study highlights the fact that pancytopenic presentation is more common with MDS-RAEB type.

There were three cases of hypersplenism, out of which one was caused by portal hypertension due to liver cirrhosis. Only three cases of aplastic anaemia were diagnosed, of which one was due to inherited bone marrow failure syndrome, Dyskeratosis congenita.

Hemophagocytic syndrome, tuberculosis, AML, hairy cell leukaemia, multiple myeloma, myelofibrosis and druginduced pancytopenia were rare causes of pancytopenia in the study conducted by Khunger JM et al and Tilak et al.2,9 In the present study macrophage activation syndrome, myelofibrosis, chronic granulomatous lesion and marrow necrosis were rare causes leading to pancytopenia.

\begin{tabular}{|c|c|c|c|c|}
\hline Study & $\begin{array}{c}\text { Age } \\
\text { Group } \\
\text { (yrs.) }\end{array}$ & $\begin{array}{c}\text { No. of } \\
\text { Cases }\end{array}$ & $\begin{array}{c}\text { Commonest } \\
\text { Cause }\end{array}$ & $\begin{array}{c}\text { Second } \\
\text { Common } \\
\text { Cause }\end{array}$ \\
\hline $\begin{array}{c}\text { Kumar } \\
\text { et al, 2001 }\end{array}$ & All ages & 166 & $\begin{array}{c}\text { Megaloblastic } \\
\text { anaemia }\end{array}$ & $\begin{array}{c}\text { Aplastic } \\
\text { anaemia }\end{array}$ \\
\hline $\begin{array}{c}\text { Khunger } \\
\text { et al, 2002 }\end{array}$ & $2-70$ & 200 & $\begin{array}{c}\text { Megaloblastic } \\
\text { anaemia }\end{array}$ & $\begin{array}{c}\text { Aplastic } \\
\text { anaemia }\end{array}$ \\
\hline $\begin{array}{c}\text { Gupta et al, } \\
\text { 2008 }\end{array}$ & $1.5-18$ & 105 & $\begin{array}{c}\text { Aplastic } \\
\text { anaemia }\end{array}$ & $\begin{array}{c}\text { Acute } \\
\text { leukaemia }\end{array}$ \\
\hline $\begin{array}{c}\text { Present } \\
\text { Study }\end{array}$ & $2-85$ & 80 & $\begin{array}{c}\text { Megaloblastic } \\
\text { anaemia }\end{array}$ & $\begin{array}{c}\text { Acute } \\
\text { leukaemia }\end{array}$ \\
\hline \multicolumn{4}{|c|}{ Table 2. Comparison of Age Group and Common } \\
Causes of Pancytopenia
\end{tabular}

The age of the patients in the present study ranged between 2 and 85 years. Of the 80 cases, majority of patients $(25 \%)$ were in the age group between 51 and 60 yrs. with a male preponderance (Male: Female ratio of 1.3: 1). 13 patients belonged to the age group between 0 and 10 years. Of these 13 patients, 4 had acute lymphoblastic leukaemia. A study by Jain et al showed a definite male preponderance, the male-to-female ratio being 2.6: 1 and majority of cases were encountered in 3rd and 4th decades. ${ }^{3}$

\section{Clinical Features}

Most of the patients presented with fatigue followed by fever, palpitation, dyspnoea and bleeding. Other presenting symptoms were loss of appetite ( 5 cases), loss of weight ( 4 cases), numbness ( 3 cases) and abdominal pain ( 1 case). Of the 80 cases studied $72 \%$ of the patients had complaints of fatigue, $14 \%$ had palpitation, $11 \%$ had bleeding, $12 \%$ had dyspnoea and $45 \%$ had fever. Of the 18 cases of megaloblastic anaemia, majority (15 cases) presented with generalised weakness. A study conducted by Gayathri and Rao et al on 104 patients showed that the commonest clinical presentation was generalised weakness or fatigue. ${ }^{1}$ In a study by Anitha et al, most common clinical manifestation was generalised weakness or fatigue $(86.79 \%){ }^{10}$

\begin{tabular}{|c|c|c|}
\hline Study & $\begin{array}{c}\text { Most Common } \\
\text { Symptom }\end{array}$ & $\begin{array}{c}\text { Second Common } \\
\text { Symptom }\end{array}$ \\
\hline $\begin{array}{c}\text { Gayathri and Rao et al, } \\
2011(\mathrm{n}=104)\end{array}$ & $\begin{array}{c}\text { Generalised } \\
\text { weakness }\end{array}$ & Fever \\
\hline $\begin{array}{c}\text { Anitha et al, 2013 } \\
(\mathrm{n}=106)\end{array}$ & $\begin{array}{c}\text { Generalised } \\
\text { weakness }\end{array}$ & Fever \\
\hline Present Study (n=80) & Fatigue & Fever \\
\hline \multicolumn{2}{|r|}{ Table 3. Comparison of Clinical Features } \\
\hline
\end{tabular}

On examination pallor was the most common finding followed by splenomegaly, hepatomegaly, lymphadenopathy and icterus. Of the 80 cases studied, $69 \%$ of the patients had pallor, $52 \%$ had splenomegaly, $30 \%$ had hepatomegaly, $21 \%$ had lymphadenopathy and $2 \%$ had icterus. Hepatosplenomegaly was commonly seen in acute leukaemia, lymphoma and megaloblastic anaemia. Other examination findings were petechiae ( 7 cases), clubbing ( 2 cases), pedal oedema ( 2 cases) and hyperpigmentation of skin ( 4 patients). Out of the 18 cases of megaloblastic anaemia, 12 of them had pallor. Out of the 4 patients who presented with hyperpigmentation of skin, 3 had megaloblastic anaemia and one had dyskeratosis congenita. In a study by Anitha et al, the physical findings included hepatomegaly in 26 cases $(24 \%)$, splenomegaly seen in 19 cases $(17 \%)$ and lymphadenopathy in 6 cases (5\%). ${ }^{10}$

\begin{tabular}{|c|c|c|}
\hline Study & $\begin{array}{c}\text { Commonest } \\
\text { Finding }\end{array}$ & $\begin{array}{c}\text { Second Common } \\
\text { Finding }\end{array}$ \\
\hline $\begin{array}{c}\text { Anitha et al, 2013 } \\
(\mathrm{n}=106)\end{array}$ & Hepatomegaly & Splenomegaly \\
\hline $\begin{array}{c}\text { Present Study } \\
(\mathrm{n}=80)\end{array}$ & Pallor & Splenomegaly \\
\hline \multicolumn{2}{|c|}{ Table 4. Comparison of Examination Findings } \\
\hline
\end{tabular}

\section{Haematological Parameters}

\section{Haemoglobin Concentration}

The haemoglobin percentage varied from 2.9 to $9.8 \mathrm{gm} / \mathrm{dL}$. Majority of the patients (36\%) had values between 8.1 to 10.0 $\mathrm{gm} / \mathrm{dL}$. Lowest haemoglobin concentration is noted in a case of megaloblastic anaemia.

\section{Total leucocyte Count}

Total leucocyte count varies from 300-3900/cumm with majority of patients (39\%) in the range of 3001-4000/cumm. Lowest leucocyte count is noted in a case of aplastic anaemia.

\section{Platelet Count}

The platelet count ranges from 7000 to $90000 /$ cumm. About $14 \%$ had severe thrombocytopenia with values falling below $20000 /$ cumm. Lowest platelet count is noted in a case of hypoplastic marrow. 


\section{Reticulocyte Count}

The reticulocyte count ranged from $0.4-4.0$. The average count being 1.15 in case of megaloblastic anaemia.

The most common cause of pancytopenia in our study is megaloblastic anaemia. Comparison of the cell counts are done with the study by Anitha et al.10

\begin{tabular}{|c|c|c|c|c|}
\hline $\begin{array}{c}\text { Study of Cases } \\
\text { of } \\
\text { Megaloblastic } \\
\text { Anaemia } \\
\end{array}$ & $\begin{array}{l}\text { No. of } \\
\text { Cases }\end{array}$ & $\begin{array}{c}\text { Haemoglobin } \\
\text { (gm/dL) }\end{array}$ & $\begin{array}{l}\text { TLC/ } \\
\text { mm }^{3}\end{array}$ & $\begin{array}{c}\text { Platelet } \\
1000 / \mathrm{mm}^{3}\end{array}$ \\
\hline $\begin{array}{c}\text { Anitha et al, } \\
2013\end{array}$ & 106 & $1.8-9.2$ & $500-3900$ & $10-100$ \\
\hline $\begin{array}{l}\text { Present Study } \\
\quad(n=80)\end{array}$ & 80 & $2.9-9.8$ & $\begin{array}{l}1700- \\
3700\end{array}$ & $20-90$ \\
\hline Table 5. Cor & & $\begin{array}{l}\text { of Cell Couı } \\
\text { Anaemia }\end{array}$ & in Megal & loblastic \\
\hline
\end{tabular}

\section{Peripheral Smear and Bone Marrow Examination}

Red cell morphology in the peripheral smear of the studied population was normocytic normochromic in 28 patients, macrocytic in 27 patients, microcytic hypochromic in 13 patients and dimorphic in 12 patients. In study by Gayathri and Rao et al, dimorphic anaemia was the most common red cell morphology. 1

\begin{tabular}{|c|c|}
\hline Study & Red Cell Morphology \\
\hline $\begin{array}{l}\text { Gayathri and Rao et al, } 2011 \\
\qquad(\mathrm{n}=104)\end{array}$ & Dimorphic \\
\hline Present Study $(\mathrm{n}=80)$ & Normocytic normochromic \\
\hline \multicolumn{2}{|c|}{ Table 6. Comparison of Red Cell Morphology } \\
\hline
\end{tabular}

All cases of multiple myeloma showed Rouleaux formation. Anisopoikilocytosis, tear drop shaped cells and leucoerythroblastic blood picture was seen in case of myelofibrosis.

In present study, majority of patients had a hypercellular marrow (70\%). 15\% of patients had hypocellular marrow and $8 \%$ had normocellular marrow, which is comparable with a study by Anitha et al who had 73 cases (68.8\%) of hypercellular marrow followed by hypocellular marrow (16.2\%) and normocellular (15\%) marrow. Most common cause for hypercellular bone marrow was megaloblastic anaemia in the present study. Hypercellular marrow was noted in cases of MDS, multiple myeloma, NHL and subleukaemic leukaemia in the study done by Khunger et al. ${ }^{2}$

\begin{tabular}{|c|c|}
\hline Study & Marrow Cellularity (\%) \\
\hline Anitha et al, $2013(n=106)$ & Hypercellular (68.8\%) \\
\hline Present Study $(\mathrm{n}=80)$ & Hypercellular (70\%) \\
\hline \multicolumn{2}{|c|}{ Table 7. Comparison of Marrow Cellularity } \\
\hline
\end{tabular}

In majority of the cases (43\%) the marrow showed normoblastic maturation, $35 \%$ had megaloblastic maturation and $21 \%$ showed erythroid suppression. In a study by Gayathri and Rao et al, commonest erythroid morphology is megaloblastic maturation. ${ }^{1}$ Giant metamyelocyte and stab forms were noted in 10 cases of megaloblastic anaemia.

\begin{tabular}{|c|c|}
\hline Study & Erythroid Maturation \\
\hline $\begin{array}{c}\text { Gayathri and Rao et al, 2011 } \\
\text { et al (n=104) }\end{array}$ & Megaloblastic \\
\hline Present Study (n=80) & Megaloblastic \\
\hline \multicolumn{2}{|c|}{ Table 8. Comparison of Erythroid Maturation } \\
\hline
\end{tabular}

All cases of MDS showed dysplastic features, mainly in the form of megaloblastoid erythropoiesis. Decreased haematopoiesis and infiltration by blasts were seen in case of acute leukaemia. Infiltration by plasma cells with binucleate forms were seen in case of multiple myeloma. Two cases of plasmacytosis which did not meet the criteria for multiple myeloma was reported. All cases of aplastic anaemia showed mainly fat in the trephine biopsy. Hemophagocytosis was seen in case of macrophage activation syndrome. Two cases of chronic granulomatous lesion were diagnosed, of which one was due to tuberculosis. One case of Paroxysmal nocturnal haemoglobinuria was diagnosed with the help of clinical details, lab findings and PNH card test.

\section{CONCLUSION}

\section{The Conclusions of this study are-}

1. Most common cause of pancytopenia was megaloblastic anaemia followed by acute leukaemia.

2. Generalised weakness and pallor were the most common clinical manifestations in the study population. Majority of these patients had a hypercellular marrow.

\section{REFERENCES}

[1] Gayathri BN, Rao KS. Pancytopenia: a clinico hematological study. J Lab Physicians 2011;3(1):1520.

[2] Khunger JM, Arunselvi S, Sharma U, et al. Pancytopenia - a clinico haematological study of 200 cases. Indian J Pathol Microbiol 2002;45(3):375-9.

[3] Jain A, Naniwadekar M. An etiological reappraisal of pancytopenia - largest series reported to date from a single tertiary care teaching hospital. BMC Hematology 2013;13(1):10.

[4] Keisu M, Heit W, Lambertenghi Deliliers G, et al. Transient pancytopenia. A report from the international Agranulocytosis and Aplastic study. Blut 1990;61(4):240-4.

[5] Singh T. Atlas and text of hematology. $3^{\text {rd }}$ edn. India: Avichal Publishing Company 2014: p. 162-8.

[6] Kumar R, Kalra SP, Kumar H, et al. Pancytopenia: a six year study. J Assoc Physicians India 2001;49:1078-81.

[7] Jan ZA, Zahid B, Ahmad S, et al. Pancytopenia in children: a 6-year spectrum of patients admitted to Pediatric Department of Rehman Medical Institute, Peshawar. Pak J Med Sci 2013;29(5):1153-7.

[8] Gupta V, Tripathi S, Tilak V, et al. A study of clinicohaematological profiles of pancytopenia in children. Trop Doct 2008;38(4):241-3.

[9] Tilak V, Jain R. Pancytopenia - a clinico-hematologic analysis of 77 cases. Indian J Pathol Microbiol 1999;42(4):399-404.

[10] Javalgi AP, Dombale VD. Clinico - hematological analysis of pancytopenia: a bone marrow study. National Journal of Laboratory Medicine 2013;2(4):12-7. 